\title{
PENGARUH TINGGI TUMPUKAN PADA PENGOMPOSAN TANDAN KOSONG KELAPA SAWIT MENGGUNAKAN PUPUK ORGANIK AKTIF DARI LIMBAH CAIR PABRIK KELAPA SAWIT DI DALAM KOMPOSTER MENARA DRUM
}

\author{
Chamsa Triyadi, Yosi Rahman, Bambang Trisakti \\ Departemen Teknik Kimia, Fakultas Teknik, Universitas Sumatera Utara \\ Jl. Almamater Kampus USU Medan, 20155 Indonesia \\ Email: chamsa.triyadi@gmail.com
}

\begin{abstract}
Abstrak
Penelitian ini bertujuan untuk menemukan teknik pengomposan tandan kosong kelapa sawit (TKKS) dan untuk mendapatkan data degradasi pengomposan TKKS sehingga dihasilkan kompos bermutu baik. Proses pengomposan dilakukan dengan memotong TKKS menjadi 4 bagian, kemudian dimasukkan ke dalam komposter dan ditambahkan pupuk organik aktif (POA) hingga moisture content (MC) bahan mencapai MC optimum yaitu 55-65\%. Parameter yang dianalisa adalah temperatur, $\mathrm{MC}, \mathrm{pH}$, ratio $\mathrm{C} / \mathrm{N}$, daya hantar listrik, kapasitas ikat air (Water Holding Capacity, WHC), jumlah bakteri dan kualitas kompos. Hasil penelitian yang didapatkan menunjukkan bahwa kompos dapat digunakan dalam waktu 10 hari dan degradasi terbaik selama 40 hari diperoleh dengan MC 79,14 \%; pH 8,1; C 25,16\%; N 1,20\%; C/N 20,97; EC 4,725 dS/m ; WHC $60 \% ; 10^{7}$ CFU/ml.
\end{abstract}

Kata kunci: komposter, moisture content, pupuk organik aktif, tandan kosong kelapa sawit

\begin{abstract}
This research aims to determine the composting technique for Empty Fruit Bunch (EFB) and to collect the degration data during composting of EFB in order to get a high quality compost. The composting process was started with cutting the EFB into four parts before it was put into composter and then followed by the addition of Activated Liquid Organic Fertilizer (ALOF) until the optimum moisture content $(M C)$ of 55-65\% was reached. The parameters of temperature, $M C$, pH, C/N ratio, Electrical Conductivity (EC), Water Holding Capacity (WHC), Bacterial Count (BC) and the quality of compost were analyzed through the process. The results of this research showed that the compost were well done in about 10 days and the best degradation during the 40 days of composting was obtained in which value of $M C, p H, C, N, C / N$ ratio, $E C, W H C$ and $B C$ were 79,14\%; 8,1;25,16\%;1,20\%; 20,97; 4,725 dS/m;60\% and $10^{7} \mathrm{CFU} / \mathrm{ml}$, respectively.
\end{abstract}

Keywords: Activated Liquid Organic Fertilizer, Composter, Empty Fruit Brunch, moisture content

\section{Pendahuluan}

Kelapa sawit di Indonesia merupakan salah satu komoditi yang mengalami perkembangan sangat pesat. Hal ini sejalan dengan perluasan areal perkebunan kelapa sawit dan semakin meningkatnya produksi kelapa sawit pertahunnya [8].

Tabel 1. Data luas areal perkebunan kelapa sawit dan produksi CPO dari tahun 20082013[3]

\begin{tabular}{|c|c|c|}
\hline Tahun & Luas Area (Ha) & Jumlah Produksi(Ton) \\
\hline 2008 & 7.363 .847 & 17.539 .788 \\
2009 & 8.248 .328 & 19.324 .294 \\
2010 & 8.385 .394 & 21.958 .120 \\
2011 & 8.992 .824 & 23.096 .541 \\
2012 & 9.074 .621 & 23.521 .071 \\
2013 & 9.149 .919 & 24.431 .640 \\
\hline \multicolumn{2}{|c}{ Pengolahan kelapa sawit selain }
\end{tabular}

menghasilkan CPO (Crude Palm Oil) juga menghasilkan produk-produk samping dan limbah, yang bila tidak diperlakukan dengan benar akan berdampak negatif terhadap lingkungan [12]. Tandan Kosong Kelapa Sawit (TKKS) merupakan limbah terbesar yaitu sekitar $23 \%$ tandan buah segar [18].

Sebelumnya, TKKS dibakar pada incinerator untuk diabukan, dan digunakan sebagai pupuk, karena kandungan kaliumnya relatif tinggi yakni \pm $30 \%$. Tapi proses pembakaran ini sekarang dilarang berdasarkan Keputusan Mentri Negara Lingkungan Hidup nomor 15 tahun 1996 tentang Program Langit Biru, untuk mencegah polusi udara. Sehingga TKKS kini kebanyakan digunakan sebagai mulsa (material penutup tanaman budidaya) yang berfungsi sebagai pengendali gulma, mencegah erosi, dan menjaga kelembapan tanah [14]. Namun, pendistribusian TKKS ke lapangan sebagai mulsa membutuhkan biaya transportasi dan tenaga kerja yang tinggi, serta proses pembentukan kompos dari mulsa memerlukan waktu yang lama bergantung dari faktor lingkungan. Oleh karena itu, TKKS perlu dikomposkan terlebih dahulu sebelum disebar ke lapangan atau dibagikan ke petani disekitar perkebunan sawit. Beberapa studi telah dilakukan untuk pengolahan TKKS menjadi kompos diantaranya dengan menambahkan bahan tambahan seperti kotoran hewan [14], dan dengan 
pencampuran Palm Oil Mill Effluent (POME) [1]. Namun penambahan yang dilakukan dalam penelitian ini adalah Pupuk Organik Aktif (POA) yang berfungsi sebagai aktivator, sumber nutrisi dan menjaga Moisture Content (MC). Adapun tujuan dari penelitian ini adalah untuk mendapatkan data degradasi pengomposan TKKS di dalam komposter menara drum serta mengetahui kualitas kompos yang dihasilkan.

\section{Teori}

Banyak penelitian terdahulu dilakukan untuk pengolahan kompos dari TKKS. Zahrim dan Asis (2010) melakukan penelitian mengenai produksi semi-kompos tandan kosong kelapa sawit tanpa dicabik dengan mencampurkan POME. Prosesnya menggunakan metode open turned windrow dengan dimensi area panjang $4 \mathrm{~m}$, tinggi 1,5 $\mathrm{m}$ dan lebar 40 $\mathrm{m}$. Setiap windrow berisi sekitar 120 metrik ton TKKS dan 324 metrik ton POME. Proses pembalikan dilakukan pada hari ke- 10, 20, 30 dan 40. Hasil yang diperoleh menunjukkan total waktu pengomposan termasuk persiapan adalah sekitar 40-45 hari, temperatur selama pengomposan mengalami fluktuasi dimana suhu awal pengomposan adalah $53{ }^{\circ} \mathrm{C}$. Setelah dua hari, suhu turun di bawah $50{ }^{\circ} \mathrm{C}$, setelah dilakukan pembalikan pertama, terjadi peningkatkan suhu lebih dari $50{ }^{\circ} \mathrm{C}$. Pada hari 10 sampai hari 25 , suhu dipertahankan pada sekitar 45 sampai $55^{\circ} \mathrm{C}$ dengan bantuan putar yang kecil, namun pembalikan pada hari ke 40 tidak terjadi peningkatan suhu dan untuk kandungan oksigen dipertahankan di atas $10 \%$. Kompos yang dihasilkan memiliki kualitas $\mathrm{pH} 7,9$; $\mathrm{N} 1,9 \% ; \mathrm{P}_{2} \mathrm{O}_{5} 0,6 \% ; \mathrm{K}_{2} \mathrm{O} 2,0 \% ; \mathrm{MgO} 0,8 \%$ dan rasio C/N 20 [19].

Penelitian yang dilakukan oleh Kananam et al., (2011) adalah untuk mengetahui perubahan biokimia pengomposan TKKS dengan lumpur decanter dan kotoran ayam sebagai sumber nitrogen, dengan ukuran potongan TKKS 2-5 cm dan pengadukan setiap 3 hari sekali. Pada penelitian ini juga dilakukan penambahan tanah merah yang mengandung $\mathrm{Fe}$, berfungsi untuk acceptor elektron mikroorganisme dalam kondisi anaerobik, dan lumpur decanter yang digunakan berasal dari limbah pabrik kelapa sawit. Untuk kondisi aerobik pada penelitian ini ditambahkan benih mikroorganisme yang terdiri dari jamur (Corynascus sp., Scytalidium sp., Chaetomium sp., dan Scopulariopsis sp) dan bakteri (Bacillus sp), sedangkan untuk kondisi anaerobik benih mikroorganisme yang ditambahkan mengndung ragi (Saccharomyces sp), bakteri asam laktat (Lactobacillus sp), dan bakteri katabolisme protein (Bacillus sp). Hasil yang diperoleh, penggunaan decanter lumpur dan kotoran ayam dalam kondisi aerob dapat diselesaikan dalam waktu 30 hari sedangkan pada kondisi anaerob waktu pengomposan gagal diselesaikan dalam waktu 90 hari [5].

Penelitian yang dilakukan oleh Hayawin et al. (2012) mengenai vermicomposting dari TKKS dengan tambahan POME. Penelitian bertujuan untuk mengevaluasi kualitas nutrisi kompos yang dihasilkan dari TKKS dan POME dengan menggunakan epigeic cacing tanah Eisinia fetida. Prosesnya TKKS diparut menjadi bahan berserat longgar (panjang $\approx 3,68 \mathrm{~mm}$, lebar $\approx 165,45 \mu \mathrm{m}$ ) menggunakan mekanik thermo refiner. Pengomposan dilakukan pada enam unit vermicomposter dengan dimensi panjang $14 \mathrm{~cm}$, lebar $12 \mathrm{~cm}$ dan tinggi $7 \mathrm{~cm}$. Setiap vermicomposter diisi dengan komposisi TKKS dan POME yang berbeda. Setelah 15 hari TKKS dan POME dicampur pada masing - masing unit vermicomposter dengan komposisi yang telah ditentukan, lalu ditambahkan 5 gr Eisinia fetida pada masing vermicomposter dan kelembapan substrat dipertahankan sekitar $80 \pm 10$ dengan memercikan air ke bahan. Memperoleh hasil kompos terbaik dengan perbandingan komposisi $50 \%$ TKKS + 50\% POME dengan $\mathrm{pH} 8,2$ dan rasio $\mathrm{C} / \mathrm{N} 10,5 \%$ selama proses pengomposan yaitu 84 hari [4].

Penelitian yang dilakukan oleh Baharuddin et al. (2010) mengenai pengaruh dari POME anaerobic sludge yang berasal dari $500 \mathrm{~m}^{3}$ closed anaerobic methane digested tank dengan TKKS yang telah ditekan dan dirobek pada proses pengomposan. Proses dilakukan pada unit komposter berbentuk blok yang disusun dari batu bata dengan dimensi panjang 2,1 $\mathrm{m}$, lebar dan tinggi $1,5 \mathrm{~m}$. Pada penelitian ini TKKS ditekan dan dirobek dengan ukuran panjang 15 sampai $20 \mathrm{~cm}$, lalu dicampur di blok komposter dengan POME anaerobic sludge, rasio penambahan TKKS : POME sebanyak 1:1. Untuk mempertahankan kadar air tumpukan kompos, POME ditambahkan setiap tiga hari dengan menggunakan pompa dan penambahan POME dihentikan seminggu sebelum dilakukan panen sedangkan pengadukan dilakukan tiga kali seminggu. Memperoleh waktu pengolahan pengomposan singkat 40 hari dengan rasio $\mathrm{C} / \mathrm{N}$ akhir 12,4 dan pH pada tumpukan kompos 8,1 - 8,6 [1].

Penelitian yang dilakukan Sahwan et al. (2004) mengenai pengomposan sampah kota skala rumah tangga. Komposter yang digunakan sebanyak 2 buah dibuat dari drum plastik dengan ukuran tinggi $94 \mathrm{~cm}$, diameter $46 \mathrm{~cm}$, volume 160 L. Drum plastik tersebut dilubangi pada sekeliling bagian atas, sekeliling bagian bawah dan pada seluruh bagian alasnya dengan masing-masing lubang berdiameter $2,5 \mathrm{~cm}$. Komposter I tanpa pembalikan, sedangkan komposter II dengan pambalikan satu minggu sekali. Memperoleh waktu pengomposan singkat 56 hari dengan rasio $\mathrm{C} / \mathrm{N}$ $18,4 \%$ dan $\mathrm{pH} 8,48$ [9]. 


\section{Metodologi Penelitian}

Bahan baku dari penelitian ini adalah tandan kosong kelapa sawit (TKKS) diperoleh dari PKS Sei Mangkei PTPN III dan pupuk organik aktif (POA) (sebagai aktivator, sumber nutrisi dan menjaga $\mathrm{MC}$ ) diperoleh dari hasil pengolahan Limbah Cair Pabrik Kelapa Sawit (LCPKS) dari Pilot Plant Pembangkit Listrik Tenaga Biogas, Pusdiklat LPPM, USU, Medan. Bahan tambahan adalah aquades $\left(\mathrm{H}_{2} \mathrm{O}\right)$ sebagai pelarut untuk analisa $\mathrm{pH}$.

Peralatan utama yang digunakan adalah menara drum komposter dengan ukuran 45 x 300 $\mathrm{cm}$ yang dilengkapi 3 lubang sampling (ketinggian $1 \mathrm{~m}, 2 \mathrm{~m}$ dan $3 \mathrm{~m}$ ) sebagai tempat analisa suhu dan pengambilan sampel. Komposter ini juga memiliki lubang asupan udara dengan diameter $1,25 \mathrm{~cm}$ sebanyak 57 buah lubang. Peralatan analisa yang digunakan adalah termometer, $\mathrm{pH}$ meter, oven, dan desikator.

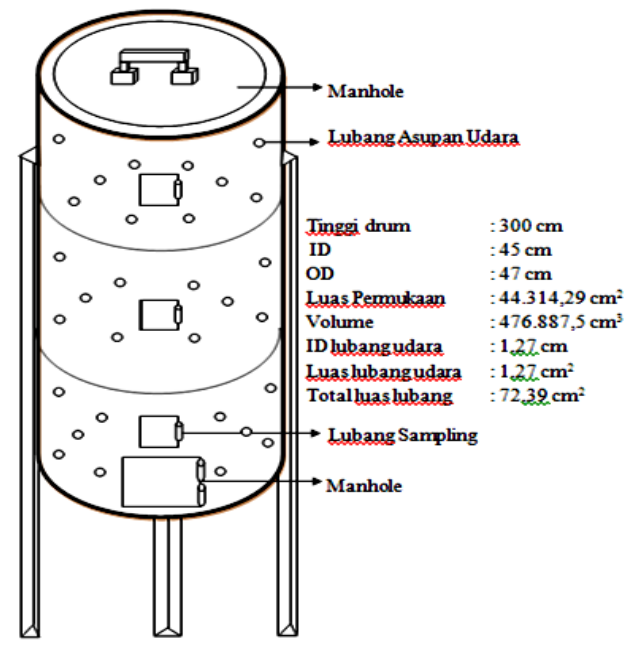

Gambar 1. Skema dan Dimensi Menara Drum Komposter

Penelitian ini dilakukan di Pilot Plant Pembangkit Listrik Tenaga Biogas, Pusdiklat Lembaga Pusat Penelitian Mahasiswa (LPPM), Universitas Sumatera Utara (USU), Medan. Proses pengomposan dilakukan dengan terlebih dahulu mempersiapkan drum komposter, lalu mencabik TKKS menjadi 4 bagian, setelah itu dimasukkan TKKS kedalam komposter, kemudian ditambahkan POA hingga kadar MC mencapai 55-65\% dan dilakukan recycle cairan yang turun dari komposter setiap hari selama proses pengomposan. Pengukuran suhu dilakukan setiap 2 kali sehari (pagi dan sore) pada tiap lubang sampel, pengukuran MC dilakukan sekali setiap hari pada tiap lubang sampel, pengukuran $\mathrm{pH}$ sekali setiap hari, analisa Electrical Conductivity setiap 10 hari sekali, analisa Bacterial Count setiap 10 hari sekali dan analisa $\mathrm{C} / \mathrm{N}$ setiap 10 hari sekali serta kualitas kompos dilakukan setelah proses pengomposan selesai.

\section{Hasil \\ Profil dan Analisis Kompos Berdasarkan Suhu}

Temperatur merupakan hal yang penting untuk diukur dalam proses pengomposan [11]. Keberlangsungan proses pengomposan pada komposter dapat dilihat dari perubahan suhu selama proses pengomposan. Pengukuran suhu kompos setiap hari dilaksanakan pada pagi dan sore. Pada setiap pengukuran, dibaca suhu pada ketinggian $1 \mathrm{~m}, 2 \mathrm{~m}$ dan $3 \mathrm{~m}$. Pengaruh tinggi tumpukan terhadap suhu tampak pada Gambar 2, dimana suhu tertinggi terdapat pada ketinggian $1 \mathrm{~m}$. Peningkatan suhu dengan semakin dalamnya tumpukan kompos diakibatkan oleh porositas pada tumpukan, hal ini sesuai dengan yang disebutkan oleh Van Ginkel et al (1999), perpindahan massa dan panas pada tumpukan kompos secara signifikan dipengaruhi oleh geometri dan distribusi ukuran pori-pori serta komposisi bahan kompos[17]. Dengan semakin dalamnya tumpukan, porositas pada tumpukan akan semakin kecil sehingga menyebabkan banyaknya panas yang dihasilkan selama proses dekomposisi terperangkap didalam tumpukan.

Setelah hari ke-15, profil suhu pada ketinggian 3 meter terhenti disebabkan terjadinya penyusutan volume kompos yang melebihi 1 meter.

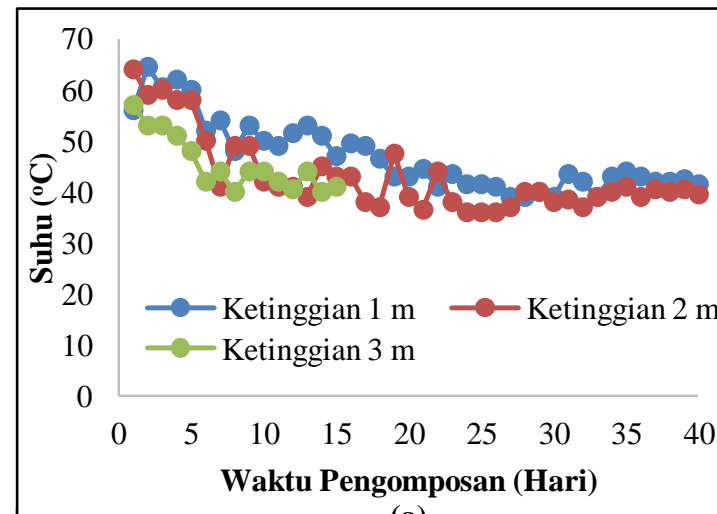

(a)

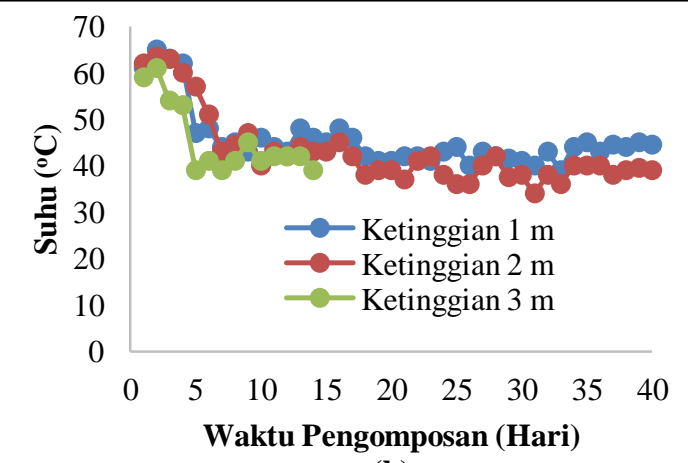

(b)

Gambar 2. Profil Suhu Pengomposan (a) Waktu Pagi Hari (b) Waktu Sore Hari 
Tabel 2. Hasil Analisa Karakteristik TKKS PKS Rambutan PTPN III dan POA

\begin{tabular}{|c|c|c|c|c|}
\hline Parameter & Satuan & TKKS & POA & Metode Pengukuran \\
\hline $\begin{array}{c}\text { Moisture } \\
\mathrm{pH} \\
\mathrm{C} \\
\mathrm{N} \\
\mathrm{C} / \mathrm{N} \\
\mathrm{WHC} \\
\mathrm{P}_{2} \mathrm{O}_{5} \\
\mathrm{~K}_{2} \mathrm{O} \\
\mathrm{COD} \\
\end{array}$ & $\begin{array}{l}(\%) \\
(\%) \\
(\%) \\
(\%) \\
(\%) \\
\mathrm{mg} / \mathrm{l}\end{array}$ & $\begin{array}{c}43,8286 \\
9,1 \\
33,15 \\
0,99 \\
33,48 \\
62\end{array}$ & $\begin{array}{c}8,09 \\
0,58 \\
0,10 \\
5,8 \\
0,016 \\
0,167 \\
1.580\end{array}$ & $\begin{array}{l}\text { SNI 03-1971-1990 } \\
\text { Menggunakan pH meter dengan metode } \\
\text { Potensiometri } \\
\text { Metode Walkley \& Black } \\
\text { Metode Kjeldahl } \\
\text { Pembagian kadar C/N } \\
\text { ASTM D7367-07 }\end{array}$ \\
\hline
\end{tabular}

Tabel 3. Karakteristik Kompos Setelah 40 Hari

\begin{tabular}{|c|c|c|c|c|c|}
\hline \multirow{2}{*}{ Parameter } & \multirow{2}{*}{ Satuan } & \multirow{2}{*}{ TKKS Awal } & \multirow{2}{*}{ Kompos } & \multicolumn{2}{|c|}{ SNI } \\
\hline & & & & Minimum & Maksimum \\
\hline $\mathrm{MC}$ & $(\%)$ & 43,8286 & 79,14 & - & 50 \\
\hline $\mathrm{pH}$ & & 9,1 & 8,1 & 6,8 & 7,49 \\
\hline WHC & $(\%)$ & 62 & 60 & 58 & - \\
\hline $\mathrm{C}$ & $(\%)$ & 37,89 & 25,16 & 9,80 & 32 \\
\hline $\mathrm{N}$ & $(\%)$ & 1,22 & 1,20 & 0,40 & - \\
\hline $\mathrm{C} / \mathrm{N}$ & & 31,06 & 20,97 & 10 & 20 \\
\hline $\mathrm{Na}$ & $(\%)$ & 0,102 & 0,059 & & \\
\hline $\mathrm{CaO}$ & $(\%)$ & 1,759 & 2,043 & $*$ & 25,50 \\
\hline $\mathrm{MgO}$ & $(\%)$ & 0,527 & 0,250 & $*$ & 0,60 \\
\hline $\mathrm{P}_{2} \mathrm{O}_{5}$ & $(\%)$ & 0,201 & 0,091 & & \\
\hline $\mathrm{Cd}$ & $\mathrm{ppm}$ & 0,894 & 0,437 & $*$ & 3 \\
\hline $\mathrm{Cu}$ & ppm & 0,673 & 0,078 & $*$ & 100 \\
\hline $\mathrm{Fe}$ & ppm & 1,073 & 0,051 & * & 2,0 \\
\hline $\mathrm{Pb}$ & $\mathrm{ppm}$ & 1,246 & 0,080 & $*$ & 150 \\
\hline $\mathrm{Zn}$ & $\mathrm{ppm}$ & 2,370 & 0,052 & $*$ & 500 \\
\hline
\end{tabular}

* Nilainya lebih besar dari minimum atau lebih kecil dari 


\section{Profil dan Analisis Kompos Berdasarkan Moisture Content}

Moisture Content (MC) adalah parameter penting untuk mengoptimalkan proses pengomposan. Menurut Siong et al., ketergantungan mikroba terhadap air untuk mendukung pertumbuhannya dapat mempengaruhi biodegradasi bahan-bahan organik [13]. Pada penelitian ini, penambahan POA ke TKKS selain untuk menambah mikroba dan nutrisi, juga untuk mempertahankan nilai MC berkisar 55-65\%. Profil hasil analisa MC pada komposter dapat dilihat pada Gambar 3.

Pada Gambar 3, terlihat profil MC terhadap waktu pengomposan. Terlihat adanya perbedaan nilai yang tidak terlalu signifikan antara setiap ketinggian. Hal ini disebabkan distribusi POA pada komposter yang merata.

MC hari pertama setelah penambahan POA berturut-turut ketinggian $1 \mathrm{~m}, 2 \mathrm{~m}$ dan $3 \mathrm{~m}$ adalah sebesar 59,66; 49,78 dan 66,48 \%. Penambahan POA dilakukan pada hari ke-1, 2, dan 19 serta recycle cairan yang turun dari komposter setiap hari. Pada 10 hari pertama terlihat pada ketinggian 1 meter MC perlahan meningkat disebabkan distribusi POA yang perlahan turun dari ketinggian 3 meter dan tertahan didasarnya. Pada ketinggian 2 meter dan 3 meter MC perlahan menurun yang disebabkan distribusi POA yang tidak merata serta peningkatan suhu akibat proses degradasi. Hal tersebut sesuai dengan yang dilaporkan Tiquia et al. bahwa tingginya suhu dalam pengomposan bisa menyebabkan hilangnya air terus-menerus dalam bentuk penguapan [16].

Ketidakteraturan profil MC pada grafik disebabkan pengambilan titik sampel pada beberapa bagian yang tidak sama. Penyimpangan terjadi pada ketinggian $1 \mathrm{~m}$ pada hari ke-35, 36, 37, 38 dan 40, pada ketinggian $2 \mathrm{~m}$ pada hari ke- 35 sampai 37 dan pada ketinggian $3 \mathrm{~m}$ pada hari ke-15 dimana MC berada diatas $80 \%$. Penambahan POA tidak dilakukan untuk menghindari MC melebihi $80 \%$ sesuai dengan yang dilaporkan Tiquia et al. bahwa kadar air sekitar $40-60 \%$ diperlukan untuk kelangsungan hidup mikroba sementara itu kadar air melebihi $80 \%$ bisa membunuh mikroba aerobik karena kekurangan udara [16].

MC akhir ketinggian 1 dan 2 meter diperoleh sebesar $77,60 \%$ dan $80,68 \%$ dengan rataratanya sebesar $79,14 \%$.

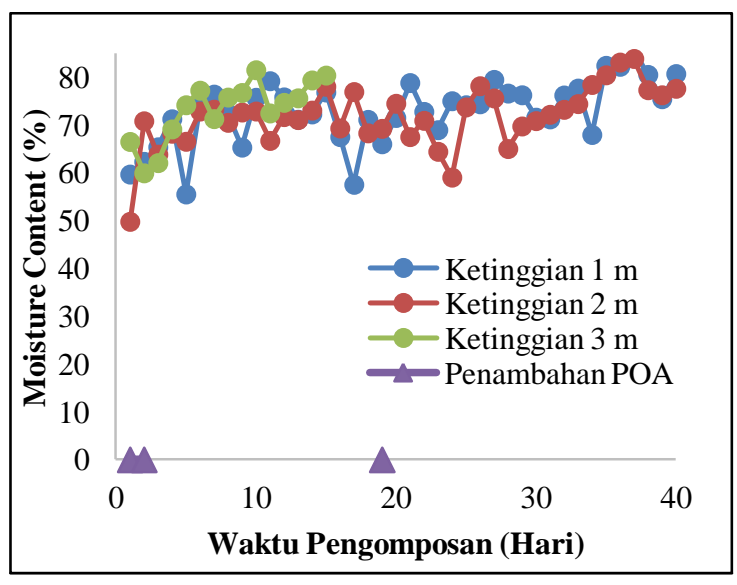

Gambar 3. Profil Moisture Content Pengomposan TKKS

Profil dan Analisis Kompos Berdasarkan pH

Untuk melihat keberlangsungan proses pengomposan, maka perlu diukur $\mathrm{pH}$ kompos dalam komposter setiap hari sekali. Data hasil pengukuran $\mathrm{pH}$ pada komposter disajikan pada Gambar 4.

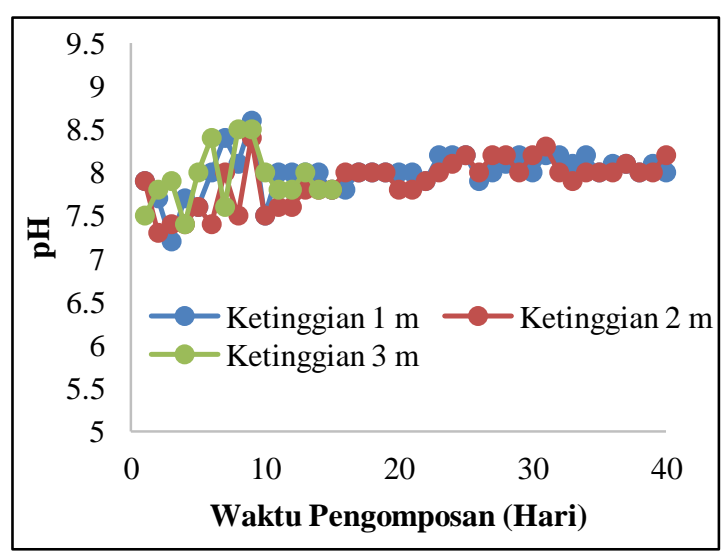

Gambar 4. Grafik Tinggi Tumpukan Terhadap pH

Pada Gambar 4, rentang pH selama 40 hari pengomposan adalah berkisar antara 7,2 hingga 8,6 yang cenderung bersifat basa. $\mathrm{pH}$ dari setiap ketinggian berfluktuasi pada 10 hari pertama lalu cenderung konstan hingga hari ke-40.

Perubahan $\mathrm{pH}$ selama proses pengomposan diakibatkan oleh aktifitas mikroba $[5,15]$. Peningkatan $\mathrm{pH}$ hingga hari ke-10 yang puncaknya mencapai 8,6. Namun pada hari berikutnya cenderung menurun sampai skala 7,6 dan mengalami peningkatan hingga 8,3. Hingga pada akhirnya kompos berada pada $\mathrm{pH} 8$ dan 8,2 pada ketinggian 1 dan 2 meter.

Secara keseluruhan kondisi yang terjadi selama pengomposan cenderung basa yaitu rata-rata berkisar 8 . Hal ini terjadi karena adanya lubang aerasi pada komposter yang digunakan. Dengan adanya lubang aerasi ini dapat mengeluarkan $\mathrm{CO}_{2}$ yang terperangkap dalam ruang kosong antar partikel kompos, sehingga mencegah terjadinya kondisi asam pada tumpukan atau penurunan $\mathrm{pH}$ 
yang signifikan [2,6]. Meningkatnya $\mathrm{pH}$ menjadi kondisi basa baik untuk proses pengomposan. Karena kondisi basa dapat menghambat pertumbuhan patogen seperti jamur yang dapat hidup dalam kondisi asam [10].

\section{Analisis Kompos Berdasarkan Bacterial Count Terhadap Suhu}

Untuk melihat pertumbuhan mikroba selama proses pengomposan perlu dilakukannya analisa Bacterial Count (BC) sehingga dapat dilihat perubahan jumlah koloni mikroba selama terjadinya proses pengomposan. Analisa BC dilakukan dengan menggabungkan sampel untuk semua ketinggian. Grafik BC yang disertakan dengan grafik perubahan suhu yang telah dirata-ratakan menggunakan error bar pada komposter ditunjukkan pada Gambar 5.

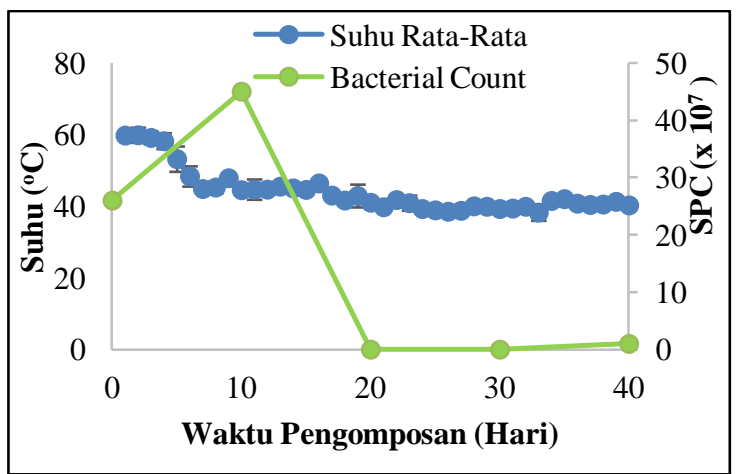

Gambar 5. Grafik Bacterial Count dan Suhu Selama Pengomposan

Berdasarkan profil suhu pada Gambar 5, terlihat adanya 2 fase selama proses pengomposan, yaitu fase termofilik (setelah 24 jam penambahan POA hingga hari ke-20) dan mesofilik (hari ke-21 hingga hari ke-40). Nilai awal BC adalah $26 \times 10^{7}$. Kemudian memasuki fase termofilik setelah 24 jam penambahan POA, nilai BC mengalami kenaikan. Hal ini disebabkan ketersediaan nutrisi, bakteri mesofilik yang bertahan pada fase termofilik mengalami pertumbuhan. Pada hari ke-10 hingga ke-40, nilai BC mengalami penurunan drastis yaitu $45 \times 10^{7}$ menjadi $1 \times 10^{7}$. Hal ini dikarenakan jumlah bakteri perlahan mulai berkurang seiring dengan menurunnya ketersediaan nutrisi.

\section{Analisis Kompos Berdasarkan C/N}

Untuk mengetahui kualitas kompos yang dihasilkan pada komposter, maka perlu diukur perbandingan $\mathrm{C} / \mathrm{N}$ yang dilakukan sebanyak 5 kali selama proses pengomposan, dan ditampilkan pada Gambar 6.

Pada gambar 6 tampak perubahan $\mathrm{C} / \mathrm{N}$ terhadap waktu. $\mathrm{C} / \mathrm{N}$ dianalisa sebanyak 5 kali selama proses pengomposan dari hari ke-0 sampai hari ke-40. Nilai C/N awal TKKS adalah 31,06, setelah proses pengomposan nilai $\mathrm{C} / \mathrm{N}$ berkurang drastis menjadi 20,99 pada hari ke-10. Pada hari ke20 hingga ke-40 nilai $\mathrm{C} / \mathrm{N}$ cenderung konstan pada range 20 hingga 21. Pada akhir proses pengomposan, didapat nilai $\mathrm{C} / \mathrm{N}$ sebesar 20,97.

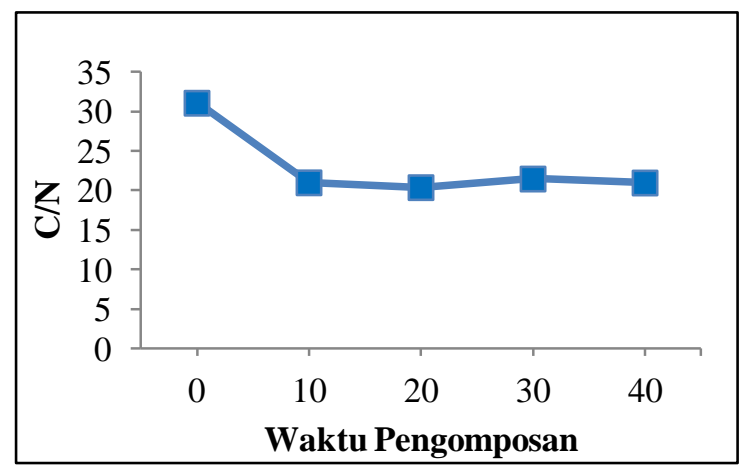

Gambar 6. Grafik C/N Selama Pengomposan

Penurunan nilai perbandingan $\mathrm{C} / \mathrm{N}$ adalah akibat penurunan kadar $\mathrm{C}$ selama pengomposan. Hal ini terjadi karena adanya proses dekomposisi bahan organik dari hasil aktivitas mikroba [13]. Nilai perbandingan $\mathrm{C} / \mathrm{N}$ merupakan salah satu indikator penting yang menyatakan kematangan kompos [1,7]. TKKS awal memiliki nilai perbandingan $\mathrm{C} / \mathrm{N} \quad 31,06$ dan hasil akhir pengomposan menunjukkan nilai perbandingan $\mathrm{C} / \mathrm{N}$ menjadi 20,97. Hal ini sesuai dengan nilai $\mathrm{C} / \mathrm{N}$ yang telah dilaporkan oleh Baharuddin dan Zahrim yaitu $20[1,19]$.

\section{Kesimpulan}

Adapun kesimpulan yang didapatkan dari penelitian kompos ini adalah sebagai berikut:

1. TKKS dengan campuran POA sebagai sumber mikroba, sumber nutrisi dan penyangga MC terbukti dapat menghasilkan kompos lebih kurang 10 hari.

2. Tinggi tumpukan mempengaruhi suhu, $\mathrm{pH}$, dan MC.

3. Kualitas kompos pada hari ke-40 tidak begitu jauh berbeda dengan hari ke-10, ini ditunjukkan dengan penurunan $\mathrm{C} / \mathrm{N}$ dari 20,99 ke 20,97.

4. Kualitas kompos yang dihasilkan selama 40 hari adalah kompos dengan $\mathrm{pH} 8,1, \mathrm{MC} 79,14 \%$, WHC $60 \%$, C 25,16\%, N 1,20\%, $\mathrm{P}_{2} \mathrm{O}_{5} 0,091 \%$, $\mathrm{Na} \mathrm{0,059 \% ,} \mathrm{CaO} 2,043 \%, \mathrm{MgO} 0,250 \%, \mathrm{Cd}$ 0,437 ppm, Cu 0,078 ppm, Fe 0,051 ppm, Pb $0,080 \mathrm{ppm}, \mathrm{Zn} 0,052 \mathrm{ppm}$ dan perbandingan C/N 20,97.

\section{Daftar Pustaka}

[1] Baharuddin, Azhari Samsu, Lim Siong Hock, Mohd Zulkairi Md Yusof, Nor Aini Abdul Rahman, Umi Kalsom Md Shah, Mohd Ali Hasan, Minato Wakisaka, Kenji Sakai, Yoshihito Shirai, Effects of Falm Oil Mill Effluent (POME) Anaerobic Sludge From 50 $\mathrm{cm}^{3}$ of Closed Anaerobic Methane Digested Tank on Pressed-Shredded Empty Fruit Bunch (EFB) Composting Process, African Journal of Biotechnology vol. 9(16), pp, 2427-2436, 19 April 2010. 
[2] BPS. Statistik Kelapa Sawit Indonesia,Katalog BPS : 5504003, 2011.

[3] Direktorat Jenderal Perkebunan. http://www. deptan.go.id/infoeksekutif/bun/BUNasem2014 /Areal-KelapaSawit.pdf. html, 2014, diakses pada 4 Februari 2014.

[4] Hayawin, Nahrul Z, Astimar, A A, Hakim, M, Khalil Abdul, H P S, Ibrahim, Zawawi, Vermicomposting Of Empty Fruit Bunch With Addition Of Palm Oill Mill Effluent Solid, Journal of Oil Palm Research 24:1542-1549, 2012.

[5] Kananam Wathida, Tachapattaworakul, T S, Chaisri, Suksaroj, Biochemical Changes During Oil Palm (Elaeis guineensis) Empty Fruit Bunches Composting With Decanter Sludge and Chicken Manure, Science Asia 37:17-23, 2011.

[6] Liu, Hong-Taw, Lu, Cai, Effect of Sewage Sludge Addition on The Completion of Aerobic Composting of Thermally Hydrolyzed Kitchen Biogas Residue, Journal of Bio Bioresource Technology 9 (3): 4862-4872, 2014.

[7] Nutongkaew, Tanawut., Wiriya, Duangsuwan, Suteera, Prasertsan dan Poonsuk Prasertsan. Production of Compost from Palm Oil Mill Biogas Sludge Mixed With Palm Oil Mill Wastes and Biogas Effluent, Thailand : Tiche International Conference, Paper Code : fb106, 2011.

[8] Rahayu, Mutiara, Skripsi, Analisis Kadar Air, Fosfor, Kalium dan Karbon Pada Kompos Yang Dibuat Dari Tandan Kelapa Sawit Dengan Aktivator Lumpur Aktif PT Coca-Cola Bottling, Universitas Andalas, Padang, 2011.

[9] Sahwan, Firman L., Rosdiana Irawati dan Feddy Suryanto, Efektivitas Pengkomposan Sampah Kota Dengan Menggunakan Komposter Skala Rumah Tangga, Jurusan Teknik Lingkungan P3TL-BPPT 5 (2): 134-139, 2004.

[10] Saidi, N, Cherif, M, Jedidi, N, Mahrouk, M, Fumio, M, Boudabus, A, Hassen, A, Evolution of Biochemical Parameters During Composting of Various Wastes Compost, American Journal of Enviromental Science 4 (4): 332-341, 2008.

[11] Saidi, s, Hasani, M, Hashemi, J, Amini, M, Investigation of Optimum Conditions of CoComposting Process BY Using of Sewage Sludge and Municipally Waste, The $1^{\text {th }}$ International and the $4^{\text {th }}$ National Congress on Recycling of Organic Waste in Agrilcultural, 2012.

[12] Sibarani, Johan., Syahrul Khairi, Yoeswono, Karna Wijaya, Iqmal Tahir, Effect of Palm Empty Bunch Ash On Transesterification of Palm Oil Into Biodiesel, Indo J Chem, 7(3), 314-319, 2007.

[13] Siong, Lim Hock, Samsu, A B, Najib, M A, Kaisom, U M, Ami, N A R, Abd-Aziz, S, Ali,
M A,Yoshito, S, Physicochemical Changes in Undrow Co-Composting Process of Oil Palm Mesocarp Fiber and Palm Oil Mill Efluent Anaerobic Sludge, Australian Journal of Basic and Applied Sciences, 3 (3): 2809-2816, 2009.

[14] Suhaimi, M, dan Ong, H K Composting Empty Fruit Bunches Of Oil Palm, Malaysian Agricultural Research and Development Institute (MARDI), 2001.

[15] Sundberg, C, Smars, S, Jonsson, H, Low pH as an Inhibiting Factor in the Transsition From Mesophilic Phase in Composting, Journal of Bioresource Technology 95: 145-150, 2004.

[16] Tiquia, Sonia.M, Judy H C, Wan, Nora F Y Tam, Dynamics of Yard Trimmings Composting as Determined by Dehydrogenase Activity, ATP Content, Arginie Ammonification, and Nitrification Potential, Journal Process Biochemistry, 37: 1057-1065, 2001.

[17] Van Ginkel, J T, P A C Raats, I A Van Haneghem, Bulk Density and Porosity Distribution in Compost Pile, Netherlands journal of agricultural science 47(1999) 105121

[18] Widiastuti, Happy dan Tri Panji, Pemanfaatan Tandan Kosong Kelapa Sawit Sisa Jamur Merang (Volvariella volvaceae) (TKSJ) Sebagai Pupuk Organik Pada Pembibitan Kelapa Sawit, Menara Perkebunan, 75 (2), 70 79, 2007.

[19]Zahrim, A Y dan Asis, T, Production Of Non Shredded Empty Fruit Bunch Semi Compost, Journal The Institution of Engineers Malaysia, Vol 71, No 4:11-1, December 2010. 